\title{
Formação econômica do Brasil, cinquenta anos depois
}

Alexandre de Freitas Barbosa ${ }^{1}$

FURTADO, Celso. Formação econômica do Brasil. Edição

comemorativa - 5o anos. São Paulo: Companhia das Letras, 2oog. ${ }^{2}$

Por que fazer a resenha de um livro que virou clássico? Por simples deleite comemorativo? Ou quem sabe se trate de uma não-resenha, já que o livro dispensa apresentações? Será mesmo?

Dois motivos me levaram a escrevê-la. Primeiro, porque era importante para mim: sem essa obra eu não seria economista, tampouco historiador, muito menos esta mistura estranha de economista com historiador. Venho, pois, saldar uma dívida pessoal. Mas também - e este motivo é mais nobre - porque a leitura desta obra pode fazer bem às novas gerações e ao país que encontrarão pela frente. Como se sabe, a história de um clássico está sempre se refazendo por meio de sua eterna procissão de leitores.

O texto que segue está estruturado em três atos: 1) vida material e afetiva de Formação econômica do Brasil; 2) o porquê do livro ter causado tanto impacto no seu tempo; 3) a razão dele poder continuar a fazer história para quem o percorre depois do governo Lula.

Pois então, mãos à obra.

Outro dia um colega me perguntou se eu poderia lhe recomendar um bom manual de economia brasileira para cursos de graduação. Minha resposta foi peremptória. Não posso, porque existe Celso Furtado.

Justiça seja feita aos outros demiurgos da formação econômica do Brasil, a mera existência de Caio Prado Jr., Celso Furtado e Ignácio Rangel inviabiliza qualquer tentativa de padronização do conhecimento sobre o tema. Pontos de partidas semelhantes conduzem a veredas muito peculiares, que, por vezes, se interpenetram, e outras tantas se apartam.

1 Professor de História Econômica do IEB/USP e Doutor em Economia Aplicada pela Unicamp.

2 Muitos dos artigos aqui mencionados foram reunidos e publicados em Formação econômica do Brasil. Edição comemorativa - jo anos. São Paulo: Companhia das Letras, 2009, porém as citações do texto de Celso Furtado se referem à edição de 1959 (FURTADO, C. Formação econômica do Brasil. Rio de Janeiro: Fundo de Cultura). 
Torna-se assim supérfluo qualquer recorte analítico sobre a economia brasileira que não recorra a estes três intérpretes e ao confronto de suas proposições. Ou seja, os alunos devem lê-los no original.

Em minhas aulas, costumo dizer também que Celso Furtado não se xeroca. Formação econômica do Brasil é um livro que todo jovem deve ter na estante, faça ou não os cursos de economia, história e ciências sociais. Aqueles já de mais idade, e que passaram pela universidade, deveriam tê-lo porque um dia foram moços. Como alguns destes ex-jovens se perderam pelo caminho, os exemplares do maravilhoso opúsculo podem ser encontrados a preços módicos em qualquer sebo pelo Brasil afora. E o jovem deste mal entrado século XXI, pode então adquiri-lo sem comprometer o orçamento de estudante. Há males que vêm para bem...

A título de depoimento, devo dizer que não compreendi Formação econômica do Brasil na graduação, mesmo tendo me dedicado a sua leitura com afinco e aprendido algo. Muitas das passagens que eu não pude ou soube assimilar apenas me foram elucidadas quando o livro virou meu ganha-pão, ou seja, em sala de aula. Isto talvez se explique pelo fato de tê-lo lido pela primeira vez para o curso que leva o mesmo nome da obra, depois de transcorridos exatos trinta anos da sua publicação. Ora, no Brasil da hiperinflação e da eleição de Fernando Collor de Melo, o que poderia significar a leitura de Furtado?

A minha geração de economistas, diferentemente da de Carlos Lessa, "não foi iniciada pela leitura de Formação econômica do Brasil". A bem da verdade, muitos se desencaminharam por não lê-lo. Ou, talvez, fossem as tais condições objetivas que impediam a sua leitura. Tanto faz. Com este preâmbulo, quero dizer que os que se salvaram da minha geração de economistas foram apenas amadurecidos pela leitura de Furtado.

Podemos hoje somente intuir o que esta obra tenha significado na sua época. Ao ouvir o relato do professor István Jancsó, tive a impressão de que o Brasil inteiro - ou melhor, a sua elite intelectual, ainda pouco numerosa, mas comprometida com os destinos do país - despertava coletivamente para a compreensão do conteúdo guardado dentro daquele exemplar vermelho com letras garrafais amarelas, publicado pela Editora Fundo de Cultura, em janeiro de 1959, quando nosso autor já se armava para assumir a Sudene.

Promoviam-se debates e organizavam-se grupos de discussão para avaliar o seu significado naqueles anos sessenta tão vibrantes de alternativas. A primeira edição, de 5 mil exemplares, esgotara-se em menos de cinco meses. A terceira edição, de 1960, viria com uma tiragem de $10 \mathrm{mil}$ exemplares. Em 1963, Formação econômica do Brasil já ostentava cinco edições. Em artigo escrito na primeira metade dessa mesma década, o 
historiador Francisco Iglesias nos conta que "o livro está nas mãos de todos os estudantes de ciências sociais".

Até hoje, o livrinho me impressiona. O texto flui como um riacho de águas limpas e calmas até se fazer mais caudaloso e quase torrencial na última parte - quando a análise já carrega mais para o "economês" e aos apenas iniciados se exige uma dedicação quase sertaneja. É que o mesmo fora escrito para os homens públicos confrontados com os dilemas da política econômica, naquele momento em que o Brasil sofria uma ruptura nas suas bases produtivas e nas suas potencialidades como nação.

No documentário de José Mariani, O longo amanhecer(2004), mestre Furtado conta que propositadamente não se preocupara em preparar um desfecho para o livro. Buscava apontar caminhos, mas sem fechar o horizonte. O livro não podia ser conclusivo. Se assim o fosse, precisaria dizer que a lógica do processo histórico brasileiro levava sempre à concentração de renda e de poder: "as fases se sucedem e todas elas levam à mesma coisa”. Se assim tivesse procedido, seria tachado de esquerdista, além de impedir - o dizemos nós - que o livro fizesse história.

Daí a frase que encerra o livro: "sendo assim, o Brasil, ao final do presente século, ainda figurará como uma das áreas da terra em que maior é a disparidade entre o grau de desenvolvimento e a constelação de recursos potenciais" (p. 280). Esta anti-profecia era um chamado para a ação do cientista que acreditava na transformação social. Furtado tornava-se, assim, o primeiro economista a se fazer popular sem cortejar a opinião com linguagem política, segundo a sagaz observação do historiador Francisco Iglesias.

$\mathrm{O}$ autor não queria passar a impressão de que o desafio que se tinha pela frente era de pouca envergadura. O estilo elegante e escorreito, avesso a ideologias e passeatas, esmerara-se em demonstrar a lógica implacável do movimento da economia brasileira ao longo da história. A professora Kátia Mattoso, em artigo de 1998, aponta que "o homem, nesta longa viagem, parece ausente". Mas trata-se de aparência, pois, completa ela, "encontramo-lo, inteiro e em plena forma, em presença discreta, mas contínua, inscrita em cada filigrana ao longo do texto". Talvez se possa acrescentar que o homem está, principalmente, no resultado do processo, naqueles leitores ávidos e sequiosos de mudança. Que têm, a partir da leitura, a missão de impedir que a profecia se concretize.

Na obra Afantasia organizada, Furtado revela que escrevera Formação econômica do Brasil entre novembro de 1957 e fevereiro de 1958, "nas sobras de tempo que ia furtando ao festival do debate teórico de Cambridge", onde conhecera Nicholas Kaldor, Piero Sraffa e Joan Robinson, que figuram entre os principais economistas a surfarem na onda da revolução keynesiana. 
As fontes são quase todas em inglês ou francês. De historiografia brasileira, encontramos uma reedição de História econômica do Brasil, de Roberto Simonsen, que Furtado comprara em Recife, no caminho para seu breve autoexílio intelectual na Inglaterra, e um artigo escrito por Alice Canabrava. Caio Prado e o Gilberto Freyre, que estavam no seu doutorado, desaparecem.

Quem, a nosso ver, mata a polêmica em torno das citações em Formação econômica do Brasil é o historiador italiano Ruggiero Romano, em artigo de 1970. Furtado não se propusera a refutar ou aceitar as conclusões deste ou daquele autor. Queria "reconstruir por conta própria" toda uma série de mecanismos que lhe permitissem chegar ao presente. Os livros que cita são apenas obras de referência que utiliza como apoio. Avesso a ortodoxias de qualquer tipo, não desprezava nenhuma ferramenta analítica que lhe possibilitasse desvelar o real em seu movimento histórico. "Ele queria ver o mundo com seus próprios olhos", sintetiza o professor Luiz Carlos Bresser-Pereira no artigo Método e paixão em Celso Furtado.

Pouca gente sabe que os manuscritos enviados ao seu editor foram extraviados. Furtado, entretanto, por sugestão de um amigo, o microfilmara antes de remetê-lo ao Brasil. Isto fez com que ele tivesse de datilografar novamente todo o livro, aproveitando para desbastá-lo de toda "celulite verbal". O original, ele descobriria, de regresso ao Brasil, avariado, num depósito dos Correios, sob a designação de "suspeito".

Sem exageros retóricos, é preciso insistir que este livro conseguiu a rara proeza de contar analiticamente o processo de construção dos alicerces econômicos da nação e, ao mesmo tempo, alterar o seu destino. Como bem disse Francisco de Oliveira em A navegação venturosa: ensaios sobre Celso Furtado, "para o erro ou para o acerto, boa parte da política econômica nas últimas cinco décadas é uma discussão em torno das formulações de Formação Econômica do Brasil". Apenas complementaria que os liberais, ao tomarem as rédeas do país nos anos 1990, pautaram-se por uma leitura "acertada" de Furtado. Queriam desfazer o que não leram. Apenas se deram ao trabalho de inverter o sinal. Quase deixaram o Brasil na lona. Hoje Furtado dá o troco, ainda que estejamos ainda muito longe do país que a sua geração logrou construir.

Antes de prosseguirmos, faz-se importante uma retificação. Celso Furtado não escreveu Formação econômica do Brasil, de chofre, em alguns poucos meses, no seu retiro em Cambridge, como ele nos dá a entender. Isto é verdade quando se concebe a escrita como um mero ato de dispêndio de tempo e de energia. Ora, a matéria-prima do que se escreve - e é por isto que podemos lançar, no papel, ideias aos borbotões, como se estas já estivessem cuidadosamente armazenadas em algum lugar - vem da reflexão. Um caso particular em que a matéria-prima responde pela agregação de valor. 
De certa forma, esta obra começou a ser elaborada já em 1948, quando Furtado escreve a sua tese de doutorado na França, A economia colonial no Brasil nos séculos XVI e XVII, cuja publicação devemos ao professor Tamás Szmrecsányi. Mas, segundo este, entre uma obra e outra, uma mutação se processaria: o cientista social interessado tanto em história como em economia cede lugar ao profissional especializado e ao alto funcionário governamental. Ocorre que o Furtado amadurecido não soterra o jovem Furtado com tintas de historiador. A capacidade de se renovar, sem olvidar das suas incursões do passado, é a característica que sobressai no Furtado de Formação econômica do Brasil e em toda a sua obra subsequente.

Podemos ir além e dizer que o livro dormitava nas entranhas da sua infância paraibana. Todo menino ou menina tem a sua obra por ser escrita. Poucos o fazem, é certo: alguns porque não lhes foi fornecida a possibilidade de instrução, outros tantos porque vivem não-furtadianamente. Como ensina o mestre em Afantasia organizada - e talvez este lema fosse uma forma de justificar a sua labuta incessante -: "são poucas as pessoas que realizam mais do que uma fração daquilo que trazem em si como virtualidade”.

Cheguei a pensar em cortar o parágrafo acima, por soar piegas. Ao ler a Apresentação de Rosa Freire d'Aguiar Furtado para a edição comemorativa dos cinquenta anos da obra que estamos a discutir, deparo-me, incrédulo, com o depoimento de um jovem de dezoito anos em seu diário.

Este jovem, que atendia pelo nome de Celso Furtado, arvorava-se, com a soberba típica dos adolescentes, a "escrever uma História da Civilização Brasileira”, assim em maiúsculas, como se a pretensão já fosse pouca. E, depois de dizer, no mesmo tom, que partiria "do ponto de vista crítico-filosófico", arremata: "não me deixaria emaranhar pelos fatos". Nesta última frase, encontra-se o embrião do homem e de sua obra.

Não nos esqueçamos também de que, em 1954, Celso Furtado publicara A economia brasileira, contendo alguns capítulos já prontos do seu filho que viria um quinquênio adiante. Livro que tivera pouca saída e que fora custeado do seu próprio bolso.

Aqui já avulta o Furtado economista, mas a parte histórica e a econômica estão como que isoladas uma da outra. De acordo com Carlos Mallorquin, no livro Celso Furtado: um retrato intelectual, o Furtado estruturalista não havia despontado em sua plenitude. Prevalece um misto de desconfiança e de idolatria em relação às categorias da ciência econômica.

Mas é importante ressaltar que o projeto de Formação econômica do Brasil já estava lançado. No prefácio de $A$ economia brasileira, ele se propõe a responder a seguinte pergunta: "como se forma o fluxo de renda em cada um dos sistemas econômicos que se sucederam no território do país"? Ele também já se preocupa com os fatores que levam a que 
"esgotadas as possibilidades de crescimento de um sistema, a economia entre num período de transição que pode ser de atrofiamento ou de gestação de um novo sistema”. Faltava apurar o método, adquirir confiança no esforço teórico autônomo e cuidar do estilo de exposição. Era preciso deixar a matéria-prima em banho-maria, partir para outras lutas e depois encontrar tempo para arregaçar as mangas.

Aqui cabe um parêntese. O "sucesso" de Formação econômica do Brasil também se deve, e muito, ao momento histórico em que foi escrito. Furtado soube captar o espírito de sua época. Prova de que um grande escritor ou cientista não é aquele que está “à frente do seu tempo", mas justamente aquele que o vive em toda a sua plenitude, resguardando certo distanciamento que lhe permite interpretá-lo. Ao contrário da geração de 1930, que via um mundo velho ruir, e para a qual "a irrealização do presente dificultava a incorporação do passado na perspectiva do futuro", segundo a feliz interpretação de Luiz Felipe de Alencastro, na Introdução à edição comemorativa de cinquenta anos de Formação econômica do Brasil; o mundo do final dos anos 1950 era outro.

Agora, poderíamos dizer, a realização do presente permitia a incorporação do passado na perspectiva do futuro. Furtado sintetizava esta nova visão de mundo, que exigia um tipo diferente de intelectual. Não se entende a fulminante recepção que teve o seu livro, se o isolarmos da figura do militante abnegado da razão em busca de sua utopia concreta.

Concluída esta breve exposição acerca da "vida material e afetiva" de Formação econômica do Brasil, pretendo apontar porque este livrinho - o diminutivo se deve à ternura que nutre o professor pelo exemplar, quase sem lombada, de páginas desgastadas e tanta vezes rabiscadas, da 23á edição, de 1989, que o ensinou a pensar o Brasil - causou tanto impacto na época em que foi escrito.

O método é tudo em Formação econômica do Brasil. O próprio Furtado, sem se referir a sua obra magna, fornece-nos as pistas para a sua dissecação em trabalho apresentado, no ano de 1971, para um colóquio internacional, realizado em Paris, um dos sítios do seu exílio forçado.

Fala-nos, então, da relação entre análise econômica e enfoque histórico. Ele pretende "demonstrar" - este é o termo utilizado - que toda a vez que um economista se depara com um "conjunto social complexo", ele o faz a partir de uma vista global fornecida pela história. Sugere que quando a estrutura conceitual do economista é formulada apenas em nível de elevada abstração, a partir de variáveis quantificáveis, que não dialogam concretamente com a estrutura da vida econômica e social, temos uma sintaxe desprovida de significado e de qualquer potencial para uma ação política transformadora. 
O economista, portanto, não é nada sem a história, ou melhor, sem uma apreensão do significado concreto das variáveis econômicas num tempo e espaço determinados. Isto porque segundo Furtado, no artigo Analyse économique et Histoire Quantitative, “os modelos macroeconômicos não estão fundamentados a partir de uma teoria geral dos processos econômicos". São insuficientes, assim como é a história como mera coleção de fatos e olhares sobre o passado.

E aqui, nosso economista, depois de tecer loas ao enfoque histórico, dá uma chave de braço nos historiadores da economia. Se "não existe análise macroeconômica sem uma globalização histórica prévia”, a história quantitativa não resultaria frutífera, se por trás dos dados não houver um olhar que permita agrupá-los, escolhendo as variáveis fundamentais e estabelecendo alguma relação causal entre as mesmas; enfim, sem "um quadro analítico que é fornecido, essencialmente, pela ciência econômica”. Como bem sintetiza Ruggiero Romano, Furtado se aproxima da história "com humildade, mas sem se humilhar". Ao contrário, "com belo orgulho, enfrenta a história com toda a sua bagagem muito bem apetrechada”.

O que ele se propõe é mais do que um exercício interdisciplinar. Ainda de acordo com Romano, por meio deste "contínuo refluxo entre história e economia, onde a sociologia não está ausente", Furtado inova, pois o resultado tampouco é histórica econômica no seu sentido mais tradicional. $\mathrm{O}$ leitor pode encontrar historiador e economista reunidos, porém redimidos, posto que desprovidos de suas idiossincrasias particulares. Não há nem a exegese do historiador preso a um ponto do passado e nem as receitas mirabolantes dos economistas sábios, suspensos num futuro amorfo.

Não deixa de ser interessante que dois historiadores natos como Ruggiero Romano e Frédéric Mauro, ambos braudelianos convictos, reconheçam que ele utiliza a história como "meio", sem se mobilizarem para um contra-ataque frente à "invasão" da sua disciplina. Ao contrário, eles o saúdam e o recebem de braços abertos no seu campo de batalha. Isto porque Furtado tira para devolver, ou como aponta Mauro em texto de em 1972, ele reconstrói uma dinâmica econômica retrospectiva "nutrida de história e nutrindo-a bem". Ou melhor, ele nos propõe uma "economia política historicamente situada". Se é certo que ele parte do método histórico-indutivo, como ressalta o economista Bresser-Pereira, no artigo já citado, o resultado não é um puro historicismo, já que a sua capacidade lógico-dedutiva o habilita a construir modelos históricos, esmiuçando as suas potencialidades e limitações em termos de acumulação e de dinamização do fluxo de renda em cada período.

Esta fusão entre história e teoria não se viabiliza sem o poder da intuição criativa, que se exprime por meio do estilo de exposição. 
Vejamos alguns exemplos concretos retirados diretamente de Formação econômica do Brasil.

Sempre me incomodou que Furtado se referisse ao senhor de engenho como "empresário açucareiro". Hoje entendo esta terminologia como parte do seu método. Seria uma das tantas "explicações operacionais" de que faz uso Furtado - a expressão é do historiador norteamericano Warren Dean, utilizada em texto de 1965 - para tornar o leitor partícipe do processo histórico, agora que ele pode acessar seus mecanismos básicos. No fim das contas, o que pretende nosso economista historiador é acionar o multiplicador keynesiano num mundo de senhores e escravos. Por meio desta "análise keynesiana pela negativa" - como percebe R. Bielschowsky em Pensamento econômico brasileiro: o ciclo ideológico do desenvolvimentismo -, Furtado logra demonstrar como o investimento numa economia exportadora escravista é "fenômeno inteiramente diverso" quando comparado a uma economia industrial.

Na economia colonial, o pagamento aos fatores de produção vaza para o exterior, ao passo que a manutenção do escravo também representa custos fixos. Isto não significa que a economia não seja monetária, mas apenas que a renda monetária reverte ao empresário açucareiro e deste para os importadores e financiadores dos bens de capital, revelando a sua natureza meramente contábil. A macroeconomia keynesiana viaja no tempo e no espaço para explicar porque este crescimento com base no impulso externo não poderia engendrar um processo de desenvolvimento auto-propulsor (1959, cap. 9).

Paralelamente, não existe crise na economia colonial, ao menos no sentido conhecido pelas economias industriais. Ao arrefecer-se o impulso externo, a atividade açucareira se mantém em virtude dos altos custos fixos, ao passo que a economia criatória, projeção gerada pela demanda do setor açucareiro, desgarra-se do mercado e retorna à subsistência. Para entender isto, explica o Furtado nordestino, "é necessário ter em conta que a criação de gado era em grande medida uma atividade de subsistência, sendo a fonte quase única de alimentos e de uma matéria-prima (o couro) que se utilizava praticamente para tudo" (p. 76-77). O processo mais amplo ajuda a descortinar o real, tornando-o palpável, fazendo com que o olhar do leitor desça para o nível mais básico da vida material.

Percebe-se, assim, a constante criação de tipos ideais estilizados, mas que se constroem a partir das diversas experiências históricas. O estilo de exposição procura retirar o máximo do confronto - uma analogia por meio do contraste - entre estes tipos ideais não-estáticos, pois que se referem a diversas trajetórias possíveis de desenvolvimento.

Este artifício estilístico recorrente na obra, e que permite avançar seu método, aparece de forma recorrente no "confronto do 
subdesenvolvimento brasileiro com o desenvolvimento norteamericano", como apontado por Bielschowsky. O próprio Furtado se faz, ali pelo meio da obra, aquela que talvez seja a pergunta que tentara responder ao longo de sua vida intelectual: "por que se industrializaram os Estados Unidos no século XIX, enquanto o Brasil evoluía no sentido de transformar-se numa vasta região subdesenvolvida?" (p. 122).

Vários fatores são arrolados: os distintos tipos de colonização que produzem padrões peculiares de interação entre produtividade, concentração de renda e padrão de consumo; os diversos níveis de dependência com relação à metrópole; as estruturas sociais inassimiláveis; as formas distintas de atuação do Estado e as ideologias subjacentes dos homens públicos.

O contraponto entre "nós" e "eles" serve de gancho para prender a atenção do leitor, explicando porque "somos assim" e não de outra forma, sem preconceitos ou explicações fáceis. Como se o fio condutor da história e das instituições de ambos os territórios sócioeconômicos fosse recuperado de modo a iluminar, conforme as palavras de Francisco de Oliveira em seu livro supra citado, as peculiares "conexões de sentidos da ação social", mas sem sugerir que devêssemos fazer como "eles". Isto seria impossível no arcabouço teórico furtadiano.

Assim, se o herói furtadiano é Alexander Hamilton, que entendera o Smith da divisão do trabalho, e não o Visconde de Cairu, defensor dos interesses oligárquicos e do livre comércio, este é tão-somente mais um artifício a que recorre Furtado para revelar que o empresário privado dinâmico não existe sem a decisiva ação do Estado norteamericano segundo Oliveira.

De fato, o contraponto que Furtado tece entre o Hamilton "paladino da industrialização" e o Visconde de Cairu que "crê supersticiosamente na mão-invisível" (p. 123) não segue o figurino de um "bom historiador", que deveria ir às fontes, e, caso o fizesse, muito provavelmente chegaria a um olhar mais matizado, como se pode encontrar na análise desenvolvida por José Jobson de A. Arruda e Fernando Novais na Introdução ao livro Observacões sobre a franqueza da indústria e estabelecimento de fábrica no Brasil, acerca das ideias de José da Silva Lisboa, o Visconde de Cairu.

Porém, o que quer Furtado é fazer quase uma sociologia econômica das ideias possíveis em cada ponto do tempo e do espaço. E de sobra dá uma estocada no pretenso cosmopolitismo das elites brasileiras em qualquer época. Não à toa, em outra passagem, ele não deixa de azedar o "mito" Mauá, quando se refere ao fato de que a este "homem de visão e de experiência não ocorria melhor solução que essa da semisservidão de asiáticos” (p. 147). Esta maneira não-idealista de ver os homens como frutos de seu meio social, nem à frente, nem atrás da história, é uma das manifestações concretas daquilo que Oliveira chamou de "a contribuição silenciosa de Marx em Furtado". 
Este mesmo recurso estilístico, quiçá informado por uma fina ironia machadiana - ao revelar como a importação indiscriminada de ideias forâneas reforça a posição subalterna dos países periféricos e a sua condição de subdesenvolvimento -, voltaria na sua interpretação do fim da conversibilidade da moeda brasileira no último quarto do século XIX.

A “inibição mental” para empreender uma análise científica dos problemas monetários levaria a um "enorme esforço de mimetismo" das elites com relação ao que se fazia na Europa. A inconversibilidade da moeda era vista, então, como uma "patologia social" (p. 190), transplantando Furtado, desta forma, e de maneira original, o conceito de dependência da economia para o plano da ideologia e da cultura, segundo Alencastro.

Nosso autor demonstraria como, na prática, a desvalorização da moeda permitira sustentar as inversões na expansão do café sem traumatizar a economia de mercado interno que se desenvolvia no seu encalço. Como consequência, teríamos a inflação - originada do desequilíbrio externo - e o descontrole das contas públicas, via elevação da dívida externa. Enfim, uma análise ponderada, científica e sedutora, de alguém que sabe para onde está levando o leitor-homem público.

O Furtado destruidor de mitos aparece em toda a sua grandeza na discussão sobre a tardia irrupção da indústria no cenário nacional. Lança primeiramente a tese, adiante confirmada por vários historiadores, de que o Alvará de 1785 não pudera trazer impacto expressivo à colônia, até porque não se davam as condições para o desenvolvimento manufatureiro. É então que ele afirma: a primeira condição para tanto "teria de ser o próprio desenvolvimento manufatureiro português”. Óbvio, não? Porém, boa parte da historiografia pregressa se preocupara mais em lançar impropérios contra as supostas contradições do "iluminismo" português.

Mais à frente, depois de contrapor, fiel ao seu estilo, o Visconde de Cairu, agora ao Visconde de Strangford - o primeiro "antecipando" o futuro liberalismo irrefreável da potência britânica -, mais uma vez não sem uma ponta de ironia; e depois de dizer que o tratado de 1810 era, na prática, um "sistema criador de privilégios", ou seja, uma forma de comércio administrado, já que o Brasil não teria obtido livre acesso ao mercado "deles"; Furtado parte para o ataque: "não se pode afirmar que, se o governo houvesse gozado de plena liberdade de ação, o desenvolvimento econômico do país teria sido necessariamente mais intenso" (p. 115-117).

Em síntese, a carência de base técnica e de capacidade para importar (num contexto de exportações estagnadas) abortaria uma "política inteligente de industrialização", mesmo deixando de lado que esta seria "impraticável num país dirigido por uma classe de grandes senhores agrícolas escravistas" (p. 129-130). Ou seja, ele abre o horizonte, para depois fechá-lo. 
Joga uma hipótese contra outra, conjectura sobre os dados existentes para cada período, confronta-os com as interpretações de historiadores, mas sempre se protegendo prudentemente contra o vício do anacronismo a que está sujeito todo economista que se mete a historiador.

Esta análise científica, ponderada e elegante é, de acordo com Carlos Lessa, exatamente o contrário do que os adversários esperavam dele, ávidos por tachá-lo de "populista" e "esquerdista". Aliás, conforme dito por Luiz F. de Alencastro na Introdução à edição de Formação econômica do Brasil de 2009, a sua obra se caracteriza justamente pela "polidez discursiva", eximindo-se o autor de entrar em polêmicas estéreis com seus contemporâneos. O próprio texto se encarrega, auxiliado pela abordagem panorâmica e por sua lógica implacável, de nuançar fatos e lançar novas interpretações.

O seu método de transcender os espaços temporais fragmentados, ao mesmo tempo em que vasculhava os constrangimentos e potencialidades estruturais de cada período, auxiliado ainda pelo estilo de perscrutar "humildemente" o passado com o olhar arguto de economista do presente, habilitaria-o a tirar conclusões parciais sobre os sucessivos "sistemas de fluxo e distribuição de renda". Como afirmara em $A$ economia brasileira "é com o objetivo de estimular outros a repensar o mesmo assunto que publicamos este ensaio". A história não estava resolvida, nem era o seu objetivo, preocupado que estava com o feixe que liga o passado às possibilidades do presente.

Fato é que os historiadores que o seguiram não puderam se eximir de considerar suas hipóteses. Como sugere o historiador francês Frédéric Mauro, em artigo já mencionado, “seria necessário retomar cada um de seus capítulos e, com a ajuda das monografias existentes e das novas pesquisas de arquivos, fazer livros sobre eles". De fato, a historiadora Kátia Mattoso nos mostra que a questão da rentabilidade do engenho açucareiro - onde o próprio Mauro questiona a tese de Furtado, para depois ser confrontado pelo historiador norte-americano Stuart Schwartz - "permaneceria colocada" inúmeras edições depois de lançado o clássico.

Como Celso Furtado admitiria mais adiante em Afantasia organiza$d a$, seu objetivo "era avançar uma série de hipóteses interpretativas, aproximando acontecimentos em áreas diversas e tempos distintos, como quem fixa uma imagem através de seus traços mais característicos”. Esta imagem fixada, retirada do tempo histórico, e projetada para além dele, representava o movimento singular da nossa formação econômica subdesenvolvida.

A verdade é que, mesmo quando errava no varejo, Furtado geralmente estava certo no atacado. O método o protegia. Vejamos outro exemplo. Ao discutir a "economia de transição para o trabalho assalariado", ele centra o foco da sua análise nas mudanças no fluxo de renda, que trazem novas 
potencialidades e desequilíbrios para o sistema econômico ainda fundado sobre as exportações. Existe agora uma renda monetária que circula internamente e que "excede de muito a renda monetária criada pela atividade exportadora" (p. 180). Isto porque o investimento do empresário cafeeiro drena mão-de-obra do setor de subsistência, permitindo um aumento da massa de salários da economia. E mais, ao se manter constante o salário monetário no setor exportador, e elevando-se as taxas de lucro juntamente com os preços do café, o efeito sobre a renda interna, por meio dos novos investimentos, vêse potencializado. Em poucas palavras, o mercado externo e o interno podem crescer simultaneamente, e o segundo mais do que o primeiro graças ao efeito positivo trazido pela mudança nas relações de produção.

Ele consegue, desta forma, elaborar um modelo econômico, não abstrato, com o intuito de entender uma situação histórica específica. No último capítulo da série sobre o problema da mão-de-obra (cap. 24), Furtado vai construir tipos ideais para os "resultados" da Abolição no Nordeste e o Sudeste dinâmico. No primeiro caso, a mudança nas relações de trabalho é formal; enquanto, no segundo, supõe-se que a situação favorável em termos de disponibilidade de terras e de oportunidades de trabalho "valeu aos escravos liberados salários relativamente elevados” (p. 166-167). Chega a sugerir inclusive uma preferência do ex-escravo pelo ócio.

Sim, Furtado se equivoca. Em Celso Furtado: um retrato intelectual, Mallorquin sugere que ele "busca assalariados por todo lado para explicar a monetarização da economia e a expansão produtiva do setor cafeeiro". Ora, ele quer, na prática, fisgar o núcleo das possibilidades de irrupção de um setor industrial minimamente endógeno. Ao fazê-lo, pode abordar as virtualidades e limites da indústria recém-nascida, ainda que a análise da sua gênese deixe a desejar e, de fato, nem mereça a sua atenção. Contudo, os que vierem depois terão de seguir o seu rastro para propor, por exemplo, o conceito de "complexo cafeeiro".

Furtado também gostava de fazer estimativas. Os dados que manuseava eram sobremaneira limitados. Mas ele lidava com números como quem buscava novas hipóteses ou a refutação das antigas, não como quem corria atrás de certezas. Em exercício realizado no capítulo 25 de Formação econômica do Brasil, ele chega a um crescimento médio anual de 1,5\% para a renda per capita "nacional" entre 1872 e 1900. Uma rápida checada nos dados produzidos várias décadas depois por Angus Madison com os equipamentos mais refinados da estatística econômica (ver o artigo Brazilian economic performance since 1500: an overview), revela que as simulações de Furtado faziam sentido.

Sempre me incomodou este exercício numérico, mais pelas conclusões que ele tira no referido capítulo. O Brasil emparelha com os 
Estados Unidos em termos de ritmo de expansão - neste período, segundo os dados de Madison, há na verdade uma ampliação mais lenta do diferencial de renda per capita entre os dois países - e assim prossegue durante a primeira metade do século XX. O problema estaria, portanto, lá atrás, na primeira metade do século XIX, quando não conseguira o país se integrar nas correntes do comércio internacional, num momento de forte mudança das estruturas econômicas dos países mais avançados, perdendo assim o bonde da história.

Esta é uma das raras vezes em que o Furtado economista ocupa o centro do palco e asfixia o Furtado historiador. Não havia ele dito que a diferença entre Brasil e Estados Unidos era de estrutura econômica e social e dos diversos papéis do Estado e das ideologias em ambas as nações? Esta contradição entre os dois Furtados apenas se explica quando temos em mente que o nosso autor não escreve para os historiadores de hoje, mas para os homens públicos da época. O que ele quer dizer, para seus leitores e também para si, é que era possível, sim, tirar o atraso.

Para tanto, ele faz uso do artifício de colocar os países numa corrida desabalada, mas ocupando raias distintas que não interagem entre si. Ao optar por este atalho, corre o risco de inviabilizar a sua própria teoria do subdesenvolvimento, ainda em fase de elaboração quando ele escreve Formação econômica do Brasil. Esta é tão somente uma interpretação que tenta devassar o inconsciente furtadiano, onde o homem público e o intelectual travam, ao menos até 1964, uma luta sem fim, ora se somando, ora se colidindo.

Já na discussão das políticas anti-cíclicas pós-crise de 1929, realizada no capítulo 31, Furtado bate de frente com o senso comum. Utiliza o caso brasileiro para ensinar macroeconomia ao leitor. A análise é fria, cuidadosa e envolvente, mas o desenlace certeiro. Vale lembrar que esta parte do texto é aproveitada integralmente de $A$ economia brasileira. Nosso mestre, que começara o capítulo anterior enunciando o paradoxo da política de valorização do café e prosseguira com a insuficiência da correção cambial para estabilizar os preços durante a crise, prepara o terreno para afirmar que a política de defesa do setor cafeeiro significara "um verdadeiro programa de fomento da renda nacional".

Furtado como que "joga” com as percepções e indefinições ideológicas do leitor. Não seria "um absurdo colher o produto para destruí-lo"? Não, pois a racionalidade econômica prega as suas peças. Estávamos, inconscientemente, ele completa, "construindo as famosas pirâmides que anos depois preconizaria Keynes" (p. 220 e 224).

Não se trata de um argumento de autoridade. Esse mesmo capítulo conta com um exemplo numérico, uma apresentação dos dados básicos da 
economia brasileira durante os anos 1930 e uma reflexão por dentro da ciência econômica, sem abusar de conceitos abstratos. Keynes não surge aqui de chofre, pois estivera presente desde a análise da economia colonial.

A imagem das pirâmides keynesianas é usada propositadamente para mostrar que “o Brasil está fazendo antes dos outros”, está no caminho certo, em contraposição ao discurso da "vocação agrícola". Serve como artifício para dizer que agora a nossa economia pode caminhar por suas próprias pernas, algo que se torna evidente no capítulo seguinte. Então uma nova imagem em forma de título, o famoso "deslocamento do centro dinâmico", prepara o desfecho do autor, que flagra "uma situação praticamente nova na economia brasileira, a da preponderância do setor ligado ao mercado interno no processo de formação de capital” (p. 229-230).

Furtado não solta fogos ou rojões, sabe que este fim almejado é apenas o começo, sem o qual, é certo, não se pode pensar uma nação soberana. Como se ao longo de toda a obra ele esperasse por um lampejo de nação que pudesse se desenvolver, superando os obstáculos estruturais antepostos pelo modelo antigo. Neste sentido, pode-se dizer que o seu raciocínio segue a mesma tensão dialética entre colônia e nação, já presente em Caio Prado Jr., mas que ele pôde aprofundar pelo seu melhor diálogo - inclusive crítico - com as categorias econômicas.

Em síntese, para fundir a teoria econômica com a história, nosso autor precisa transcendê-las, sob pena de ficar preso a debates epistemológicos que o angustiam. Reduz a teoria ao mínimo denominador comum fornecido pela história e amplia o foco de visão desta, percorrendo séculos com sua locomotiva de generalizações fornecidas pela ciência econômica. O conteúdo apenas se revela por meio de artifícios estilísticos-metodológicos, tais como: a analogia por contraste (EUA x Brasil, café $\mathrm{x}$ açúcar, Sudeste x Nordeste); o tratamento das ideologias como representação de interesses ou como preconceitos que iludem o real; o desmonte de mitos historiográficos por meio da análise econômica do passado com conceitos modernos; e o uso recorrente de "explicações operacionais" que atuam como iluminadoras de processos complexos.

Importa frisar ainda que, apesar da llaneza no trato com o leitor ao longo da obra - como diz o economista mexicano Victor Urquidi, em artigo escrito em 1962, Furtado se abstém dos tecnicismos que costumam tornar "impenetráveis as obras de economia e soporíferas as de história" - existe como que embutida uma verve missionária. Profundamente sedutor, ele enlaça seu interlocutor do presente, fazendo-o percorrer o movimento da totalidade construída pela razão e cuja síntese está na não-inexorabilidade do subdesenvolvimento, entendido como processo histórico e não como condição natural ou passageira. Este pode ser alterado, desde que conheçamos 
suas origens e funcionamento. Não existe ciência por fora da sociedade, como também não existem possibilidades de transformação social sem intelectuais comprometidos, isto é o que nos parece dizer o mestre.

A elucidação do processo histórico não deve servir para limitar o horizonte, mas para abrir possibilidades insuspeitadas. Porém, nos ensina Furtado, tenhamos cuidado com as fórmulas fáceis. Não existem receitas mirabolantes de política econômica. O Brasil não deve necessariamente fazer "isto" ou "aquilo". Mais que soluções, devemos formular as questões pertinentes: sob que condições tais políticas podem fazer sentido, apoiadas em que grupos sociais, motivadas por que metas e destinadas a enfrentar quais desafios históricos? "Política econômica é política, antes de ser economia”, ele, certa feita, escrevera em A pré-revolução brasileira.

É como se a obra fosse conduzida de modo a conferir ao leitor a última palavra sobre os destinos da nação. Mas este o fará não impunemente, pois que o afresco furtadiano já lhe tomou a alma, não como uma camisa de força, mas sob o impulso de sua reflexão libertadora. $\mathrm{O}$ homem Furtado passa então a ser fruto de sua obra, que conseguiu ser, ao mesmo tempo, empírica, conceitual, dialética e politizadora.

Furtado encara o processo de formação da estrutura subdesenvolvida brasileira, como uma positividade. Isto porque, para ser conhecido, o mesmo deve ensejar um esforço próprio de teorização. Antes de "conhecer para poder transformar", é preciso "transformar para poder conhecer", diria este iluminista arretado. É neste sentido que Formação econômica do Brasil pôde ser também um marco para a "consolidação da consciência desenvolvimentista brasileira", conforme Bielschowsky em livro já citado. Ironia da razão: este texto nada proselitista mudou a trajetória política e intelectual de toda uma geração.

Que o Brasil e suas elites tenham desprezado Furtado no último quarto do século XX não me parece um problema em si mesmo. Aceitemos a triste realidade: Furtado, e muitos de sua geração, foram derrotados. O esquecimento de Furtado era um pré-requisito para o triunfo dos neoliberais nos anos 1990.

Por outro lado, bendita dialética! podemos reler hoje Formação econômica do Brasil sob novos prismas. Acredito sinceramente que o governo Lula, tão repleto de contradições, deva propiciar novas releituras da obra e, inclusive, a emergência de uma nova legião de jovens furtadianos. O sujeito desenvolvimento voltou a ser proferido e falar de planejamento estatal deixou de ser pecado. O mercado interno mostrou a sua força e o adjetivo nacional não se afigura mais pejorativo. Contudo, os percalços são enormes: o ufanismo do curto prazo e a formatação de coalizões políticas indiferenciadas turvam o horizonte. 
De qualquer maneira, a leitura do último capítulo Perspectiva dos próximos decênios está mais próxima do jovem brasileiro de hoje do que daquele dos anos 1980. Há que se refazer a história da economia brasileira da segunda metade do século XX sob a perspectiva furtadiana e há que se intervir na realidade das primeiras décadas do século XXI, partindo da matriz de referência do mestre - que como diz Conceição Tavares, no documentário O longo amanhecer, "nem se desanima, nem é cooptado e nem tem ataques de voluntarismo". Mas ampliando o seu foco de análise, de modo a assimilar as preocupações contemporâneas da sociedade brasileira.

Permito-me algumas sugestões, de caráter preliminar, neste sentido.

O Brasil, de 2004 a 2008, avançou de maneira mais expressiva do que a média de crescimento do PIB, em torno de 4,5\% ao ano, sugere. Voltou a gerar emprego formal, dinamizou o investimento, além de ter ampliado as exportações e diversificado o seu destino. Este avanço, entretanto, na melhor das hipóteses, apenas repôs o funcionamento do "subdesenvolvimento industrializado", agora sob novas bases, processo a ser descortinado pelas novas gerações de furtadianos. Ou seja, o maior dinamismo do mercado interno brasileiro, junto com a expansão das exportações, recoloca em um novo patamar a estrutura econômica subdesenvolvida e a condição periférica sedimentada nos anos 1970 .

Por outro lado, o intervalo de baixo crescimento e instabilidade econômica vivido no quarto de século depois de 1980 - mais os impactos trazidos pelas políticas de desregulamentação e abertura econômica dos anos 1990 - contribuíram para ampliar a heterogeneidade estrutural da economia e da sociedade brasileiras, justamente o contrário do que imaginavam aqueles que pensavam ingenuamente estar superando Furtado.

De qualquer maneira, se houve esta "exacerbação da heterogeneidade estrutural", tal como diagnosticado por Francisco de Oliveira em seu ensaio $O$ ornitorrinco de 2003, não nos parece que ela acarrete necessariamente a "impossibilidade de permanecer no subdesenvolvimento", segundo o diagnóstico deste autor.

Ao final da primeira década do século XXI, poderíamos dizer que o "ornitorrinco se move" e volta a se enquadrar na espécie dos subdesenvolvidos, o que não significa de modo algum uma volta ao passado. O subdesenvolvimento volta a se manifestar à medida que o maior dinamismo econômico assegura uma recuperação da estrutura produtiva e do papel do Estado como articulador/investidor, além de viabilizar uma tentativa - insuficiente, é certo - de atenuação das desigualdades sociais. Retoma-se inclusive uma consciência do subdesenvolvimento, ainda que se tenha vergonha de chamar o "bicho" pelo seu nome científico. 
O fato de que o Brasil possa ser visto com regozijo pelos capitais internacionais, e que o presidente Lula se poste como protagonista de uma nova geopolítica global, ao passo que as contradições internas se avultem, apenas revela que o país talvez esteja por se afirmar como uma espécie de tipo ideal do subdesenvolvimento, não apesar, mas em virtude do aggiornamento propiciado pela atual onda de globalização econômica.

De modo a finalizar esta breve tentativa de incursão furtadiana pelo Brasil contemporâneo, dinâmico e novamente subdesenvolvido - quem conhece Furtado, sabe que esta constatação não tem nada de pejorativo-; gostaria de levantar a vista para a linha do horizonte e refletir sobre os dilemas estruturais que se antepõem caso almejemos uma economia menos dependente e uma sociedade mais justa nos próximos dez anos.

O primeiro desafio está em sustentar o dinamismo do mercado interno. Este se recuperou no período recente, motivado por um conjunto de fatores: programas sociais, elevação do poder de compra do salário mínimo e expansão do investimento privado, e depois público, mas também do crédito às famílias e daquele direcionado a setores específicos. Tudo indica que, asseguradas taxas mais elevadas de crescimento econômico, este dinamismo vai depender do planejamento estatal e da adoção de políticas industriais e agrícolas minimamente coerentes, para que não apareçam gargalos em infraestrutura e na própria estrutura produtiva; e de mecanismos redistributivos mais sólidos, de modo a produzir uma sociedade mais equitativa e reduzir a heterogeneidade tecnológica.

$\mathrm{O}$ enfrentamento deste desafio deve se somar à gestação de um novo padrão de inserção do Brasil na estrutura econômica crescentemente globalizada. O Brasil não pode se conformar com a posição de exportador de commodities, de importador de capital de curto prazo, tampouco se abster de uma política para as empresas transnacionais aqui sediadas, geralmente atraídas pelo mercado interno e pela opção de montarem plataformas de exportação.

Este desafio é da mesma envergadura do primeiro e com ele se cruza, pois, do contrário, tendemos a ver nosso mercado inundado de produtos de maior sofisticação tecnológica, especialmente depois da mudança estrutural efetivada pela economia chinesa. Por sua vez, sem o dinamismo do mercado interno não teremos condições e nem economias de escala para adentrar em alguns nichos intensivos em tecnologia. A integração com os países da América do Sul e da África é uma das formas de associar ambos os desafios.

O terceiro desafio está relacionado ao papel do Estado, capaz de dinamizar a economia internamente e de abrir novos espaços em mercados externos. Esta ação do Estado para dentro e para fora não pode, 
entretanto, servir como foi no passado, apenas para turbinar o potencial de acumulação de capital do setor privado. Paralelamente, o Estado tem tarefas históricas a desempenhar, as quais apenas indiretamente repercutem no plano econômico. São as tarefas vinculadas à universalização de direitos e à promoção da cultura brasileira.

O quarto e o quinto desafios remetem ao que poderíamos chamar de um ataque às condições de reprodução da extrema desigualdade social no Brasil urbano e no Brasil rural. Ainda que as lógicas espaciais não sejam nada estanques, estamos falando de problemáticas bastante particulares e que envolvem frentes de atuação amplas e específicas ao mesmo tempo. O quadro cotidiano de violência urbana e os conflitos em torno da posse da terra, ambos descontextualizados pela hipocrisia midiática, são apenas a face mais visível desta que é a sociedade mais desigual do mundo capitalista.

Os dois primeiros desafios estão mais próximos do mundo da política econômica. Os três desafios subsequentes extravasam o universo do economista e entram em cheio no nosso dilema enquanto civilização. Todos eles exigem um espaço público que saiba incorporar as demandas da sociedade. E, mais ainda, uma esfera política que se encarregue de lidar com as muitas contradições que se farão sentir no meio do caminho.

O que se lê acima não tem a pretensão de servir de cartilha ou coisa que o valha. É apenas um exercício em busca de um modo de reflexão em desuso no Brasil. Que um professor de economia brasileira e história econômica se aventure na sua proposição talvez seja uma indicação de que os tempos são outros, de que ficou para trás a "construção interrompida".

Enfim, isto tudo - que era para ser um introito a Formação econômica do Brasil - para dizer que aqueles que, começaram a ler Furtado quando ele era tido como antiquado, têm um papel importante na definição da imagem futura da sua obra e de seu legado. Além de reconhecer, com orgulho, que o Brasil protagonizou, sob sua batuta, um dos momentos mais densos da reflexão econômica do século $\mathrm{XX}$, queremos que o método, o estilo e os temas furtadianos contaminem os que estão chegando. Que ao ser lido pelos "jovens" de hoje, o "velho" Furtado se sinta remoçado e que o país esteja novamente à altura dos grandes desafios ostentados por sua geração. Não basta ler Furtado, há que praticá-lo! 